\title{
Koronavirus v Rusku: fakta, kontexty, interpretace
}

\author{
Ladislav Zemánek \\ Univerzita Karlova v Praze, CZ
}

\begin{abstract}
ZEMÁNEK, L.: Coronavirus in Russia: Facts, Contexts, Interpretations Philosophica Critica, vol. 6, 2020, no. 1, ISSN 1339-8970, pp. 140-149
\end{abstract}

The article is concerned with the coronavirus epidemic in Russia. It aims to analyse the development dynamics of the disease and related political, economic and social measures adopted by the central and local governments, putting them into a broader socio-economic context. Conducting an analysis of chosen economic aspects and indicators, I argue that the Russian economy is better prepared for such a crisis in many respects in comparison with the Western economies. Therefore, I see the main risk for Russia and her elites not in the economic recession but in a prolonged negative epidemiologic situation and possible social as well as political consequences.

Key words: Coronavirus - Russia - Vladimir Putin - Economy - Crisis

Rusko dlouho zůstávalo epidemií koronaviru prakticky nedotčeno. Během února nebyl evidován jediný nový případ a ještě $v$ půli března zůstávaly v zemi s bezmála 150 miliony obyvatel počty nakažených omezeny na několik desítek. Zlom přišel na přelomu března a dubna. Od té doby Rusko v počtu nakažených překonalo jak Čínu, tak těžce zasažený Írán. V následující studii nejprve provedu analýzu vybraných aspektů ruské ekonomiky s cílem zhodnotit, nakolik je tamní hospodářství momentální krizí ohroženo. Následovat bude chronologický pohled na dynamiku epidemie, doplněný o přehled politických, ekonomických a sociálních opatření ze strany ruského státu. Uvedený postup umožní pojmenovat skutečné i potenciální důsledky, které krize a na ni reagující státní politika mohou mít jak pro současnou politickou elitu, tak pro ruskou společnost jako celek. 


\section{Ekonomický kontext krize}

Ruská ekonomika se dlouhodobě potýká s problémy vnitřního i vnějšího charakteru. $V$ důsledku angažmá na Ukrajině musí Rusko čelit ekonomickým sankcím ze strany západních zemí, které kromě bezprostředních negativních dopadů $v$ podobě recese vedly k revizi ekonomických, obchodních i politických vazeb a většímu důrazu na národní soběstačnost (Sergunin 2016, 208). Ruským subjektům se výrazně omezily možnosti vstupu na mezinárodní finanční trhy, a tudíž možnosti externího financování. To sice na jednu stranu limitovalo rozvoj firem, na stranu druhou je to tlačilo ke snižování vlastního zadlužení, což v obdobích krize představuje nespornou výhodu. Míra zadluženosti ruských soukromých firem již klesla pod úroveň $50 \% \mathrm{k}$ HDP. Podobný trend je možné pozorovat i v př́ípadě státního dluhu, jehož výše vůči HDP se pohybuje kolem 15 \% (průměrný státní dluh v zemích EU ke konci loňského roku činil více než 80 \% HDP, Česká republika je na tom lépe s hodnotou $29 \%$ ). Současný útlum hospodářské činnosti tak z hlediska finančních závazků mnohem silněji dopadne na západní firmy a státy než na jejich ruské konkurenty (Tabakh 2020).

$\mathrm{K}$ tomu je třeba připočíst fakt, že mezi zranitelnější jednoznačně patří spíše malé a střední podniky než velké obchodní korporace. V Rusku je přitom podíl malých a středních podniků s méně než 250 zaměstnanci na tvorbě HDP roven pouhé pětině, zatímco v rozvinutých západních ekonomikách se hodnota zpravidla pohybuje mezi 50 a $60 \%$. Sektor malých a středních podniků je v zemi navzdory rétorice vlády, která se přinejmenším deklaratorně snaží soukromé podnikání podporovat, dlouhodobě málo rozvinutý. ${ }^{1}$ Jeho místo zaujímají velké podniky s vazbami na stát či př́mo podniky se státní majetkovou účastí, které se s ekonomickým propadem vyrovnají snadněji než drobní podnikatelé.

Rusko má navíc značné finanční rezervy, které může použít. Díky politice prezidenta Vladimira Putina země dlouhodobě převádí finanční přebytky do zvláštního fondu (Ruského fondu národního bohatství), v němž byly v březnu tohoto roku naakumulovány prostředky ve výši 7,3 \% HDP. Země má po Číně, Japonsku a Švýcarsku čtvrtou největší zlatou rezervu na světě. Putin se tímto způsobem snaží o co největší nezávislost na americkém dolaru. Rezervy v hodnotě bezmála 14 bilionů korun tak nyní může použít ke stabilizaci ekonomiky, kompenzaci výpadků na straně př́jmů či k nutným sociálním opatřením a ekonomickým stimulům (The Economist

\footnotetext{
1 Ruský ekonomický systém může být charakterizován jako monopolní kapitalismus $s$ vysoce koncentrovaným vlastnictvím, kontrolou nad zpo̊soby produkce a nerovnoměrnou distribucí kapitálové renty. Kirkhamová ruský monopolní kapitalismus označuje za hybridní formu státního a podnikového korporativismu (Kirkham 2016, 115-116).
} 
2020). Významnějším problémem tak ani nemusí být prudký propad cen ropy na zhruba 30 dolarů za barel, tedy o více než polovinu ve srovnání se stavem na začátku roku. Pokud se ovšem na těchto hodnotách cena ropy dlouhodobě nezafixuje. To však v nemalé míře závisí na samém Rusku, které je v produkci ropy na třetím místě na světě.

Rusko se kromě toho musí vyrovnávat s výrazným oslabováním vlastní měny; vůči americkému dolaru rubl od ledna oslabil téměř o třetinu. Souvisí to opět s vnějšími faktory, především zhoršující se situací na mezinárodních finančních trzích, obavami z globální recese a již zmíněným prudkým pádem cen ropy. Ani oslabování rublu však pro zemi a její obyvatelstvo nemusí být zásadnější problém, protože zdražující západní produkty se do země kvůli sankcím dostávaly v posledních letech jen v omezené míře. Potenciálně problematický může být daleko spíše růst inflace, kterou bude oslabování rublu tlačit vzhůru. Opačným směrem nicméně bude působit pokles koupěschopnosti obyvatel a poptávky v důsledku krize. $\mathrm{S}$ ohledem na to, že se $\mathrm{v}$ současnosti inflace nachází na rekordně nízkých hodnotách kolem 2,5 \% (přičemž ruská centrální banka cíluje na $4 \%$ ), nemusí její nárůst vyvolávat vážnější obavy.

Epidemie tedy přišla $v$ době, kdy Rusko čelí řadě problémů jak nahodilých, tak strukturálních a dlouhodobých. Tyto obtíže se za současné situace paradoxně mohou stát výhodou, protože působí protikrizově. Ruská společnost i ekonomika jsou na nepříznivé podmínky zvyklé, a proto jsou vůči současné krizi odolnější. Ve srovnání s posledními třemi hospodářskými krizemi z let 1998, 2009 a 2015 je tak nyní země v lepší výchozí situaci - má totiž značné rezervy, relativně nízké dluhy, široký prostor pro stimulaci ekonomiky jak ze strany vlády, tak centrální banky a v neposlední řadě i psychickou odolnost. Vláda již zavádí řadu opatření na podporu domácností i byznysu a plánuje posílení státních investic. Centrální banka má zároveň s ohledem na současnou šesti procentní základní sazbu určující cenu peněz na trhu dostatek prostoru pro její další snižování, a může tak nepřímo zlevnit komerční úvěry a udržet oběh peněz v ekonomice.

\section{Chronologie koronavirové krize}

Podobně jako jiné státy i ruská vláda v reakci na šíření epidemie přikročila jednak k restriktivním opatřením, jež mají za cíl zabránit jejímu dalšímu rozvoji a minimalizovat počet nakažených, jednak k opatřením sociálního a ekonomického charakteru, jejichž smyslem je maximálně zmírnit dopady na jednotlivce i firmy a udržet v chodu národní hospodářství.

První dva př́ípady nakažených se v zemi objevily 31 . ledna, a to u čínských turistů. Ještě před tím nicméně vláda přijala první opatření 
zaměřená na čínské občany. 30. ledna byla uzavřena celá hranice s Čínou dlouhá 4300 kilometrů. Zatímco v několika př́hraničních oblastech byla zavedena karanténa a výjimečný stav, Moskva debatovala o možnostech kontrol čínských státních příslušníků v hlavním městě, což vedlo k protestům čínské strany (Trenin 2020). Začátkem února začalo být omezováno dopravní spojení mezi oběma velmocemi, probíhala evakuace ruských občanů z Číny a 20. února bylo rozhodnuto o plošném zákazu vstupu Číňanů na území federace.

Zpočátku tak restriktivní opatření směřovala výhradně proti asijskému sousedovi. To se začalo měnit $\mathrm{v}$ průběhu března, a to $\mathrm{s}$ ohledem na negativní vývoj v dalších částech Eurasie. Ruská vláda přikročila k postupnému omezování kontaktů s ostatními zeměmi a současně zachovávala poměrně volný režim uvnitř Ruska samého. Prezident přitom ponechal značnou míru volnosti jednotlivým subjektům federace tak, aby přijímaná opatření co nejvíce korespondovala se stavem a potřebami jednotlivých regionů. V první půli března došlo k výraznému omezení dopravních spojů se státy Evropské unie. $V$ případě leteckého spojení byly zachovány pouze lety polostátní společnosti Aeroflot do sedmi evropských metropolí. 16. března vláda k nelibosti prezidenta Alexandra Lukašenka rozhodla o uzavření hranice s Běloruskem, s nímž Rusko od roku 2000 tvoří unii, a to v reakci na benevolentní přístup běloruského vedení k šíření epidemie. Současná krize tak přispěla k dalšímu zhoršení bilaterálních vztahů, které jsou v posledních měsících provázeny řadou střetů a konfliktů (Шрайбман 2020). Dva dny nato byl zásadně omezen vstup cizinců na území federace, což vyvrcholilo 30 . března, kdy byly hranice uzavřeny prakticky pro všechny včetně ruských občanů. Výjimek zůstalo zachováno jen několik - týkají se např́íklad diplomatů, řidičů kamionů či obyvatel Doněcké a Luhanské lidové republiky s ruskými pasy.

Opatření směřující dovnitř země se v řadě ohledů podobají těm, která známe z Evropy. Postupně byl omezován společenský život a fungování státních, veřejných i soukromých institucí, at' už jde o muzea, divadla, kina, školy, sportovní akce či firmy. 18. března vláda přijala usnesení, jež umožňuje blokaci dezinformací týkajících se koronaviru ve sdělovacích prostředcích a následné odebrání licence. Do problémů se tak záhy dostala soukromá rozhlasová stanice Echo Moskvy, když zveřejnila informaci o vysokém počtu obětí, která se diametrálně odlišovala od oficiálních statistik. 30. března pak bylo vyhlášeno období pracovního klidu. To už bylo s ohledem na momentální situaci několikrát prodlouženo, naposledy 28. dubna s předběžnou platností do 11 . května. Za daného stavu mohou fungovat pouze státní úřady, zdravotnická zařízení, obchody s potravinami, lékárny či finanční instituce. Přesto podle dostupných údajů a provedených 
sociologických průzkumů nemalá část lidí pokračuje, nakolik to okolnosti umožňují, v práci z domova (Левада-Центр 2020).

Právě 30. březen je dnem, kdy se zvýraznil restriktivní trend. V hlavním městě byla vyhlášena sociální izolace závazná pro všechny. Ven se tak lidé od tohoto data dostali jen $\mathrm{v}$ závažných a odůvodněných př́padech, jako je nákup nezbytného zboží, cesta k lékaři či do zaměstnání. Premiér Michail Mišustin zároveň vyzval regionální vlády, aby zvážily zavedení opatření po vzoru Moskvy. Přísnější než v metropoli byl na konci března kupříkladu režim v Krasnodarském kraji, nejlidnatějším regionu po Moskvě a Moskevské oblasti, ležícím u Černého moře. Koncem měsíce tamní gubernátor zavedl všeobecnou karanténu, místní tak mohli vycházet jen do nejbližšího obchodu a lékárny, případně do práce, avšak jen s písemným povolením. Osobní automobily pak kromě jasně daných výjimek nesměly jezdit vůbec. V Moskvě samé začala být v průběhu dubna zabavována vozidla osob porušujících izolaci a zároveň bylo nařízeno, že ve vozidle smí být pouze jedna osoba kromě případů, kdy spolu cestují členové jedné domácnosti. Vedení města v čele s ambiciózním Sergejem Sobjaninem přikročilo k zavedení systému propustek, bez nichž obyvatelé nesměli opustit své domovy. $V$ půli dubna pak začaly masové kontroly na hranicích města i v metru, které je páteří moskevské dopravy. Toto opatření výrazně zkomplikovalo dopravu a přepravu cestujících, k čemuž přispěla i částečná uzavírka vybraných stanic. Situace se v tomto směru zlepšila až 22. dubna po spuštění automatizované, elektronické evidence propustek.

\section{Statistiky a jejich interpretace}

Zpřísňování opatření časově koresponduje se zrychlením v počtu případů nakažených a zemřelých. Zatímco po celý únor se oficiálně neobjevil žádný nový případ, a země tak evidovala jen dva zmíněné nemocné čínské turisty, od března začala čísla růst, byt' ve srovnání s jinými zeměmi jen pozvolna. Ještě 15 . března bylo v Rusku jen 63 nakažených, 27. března už počet nemocných překonal tisícovou hranici se 4 obětmi a od konce měsíce počty v absolutních číslech skokově narůstaly. Dlouho nebyla nákaza rozšířena ve všech regionech, což se změnilo až 16 . dubna, kdy se první případ objevil v Republice Altaj. 27. dubna Rusko v počtu nakažených předběhlo Čínu, o den později také Írán a v samém závěru měsíce, 30. dubna, byla překonána hranice 100 tisíc nakažených. Mezi nimi se ocitl i premiér Mišustin. Není nikterak překvapivé, že nejvíce případů je evidováno v Moskvě, a to přibližně polovina, dále v bezprostředně přiléhající Moskevské oblasti a Sankt-Petěrburgu. Výrazně postižena je rovněž 
Nižněnovgorodská oblast v Povolží s poměrně vysokou hustotou osídlení (Стопкоронавирус.рф 2020). K 5. květnu úřady registrovaly celkem 155370 nakažených, z nichž 1451 osob zemřelo. Procentuální přírůstek nových případů se nicméně navzdory poměrně rychlému růstu počtu nakažených podařilo $\mathrm{v}$ závěru dubna stabilizovat. Zatímco $\mathrm{v}$ březnu nebyly výjimkou denní přírůstky přes $30 \%$, během posledního dubnového týdne se hodnoty ustálily okolo 8 \% (Федеральная служба 2020).

Vysoký růst $\mathrm{v}$ absolutních číslech není důsledkem podcenění epidemiologické situace či mírnosti restriktivních opatření; ta jsou v některých ohledech mnohem přísnější, než byla ve střední Evropě. Souvisí spíše s masivnějším testováním, které přirozeně odhaluje nové případy. $S$ vědomím vážnosti situace a možných rizik se převážně pozitivní výklad vývoje epidemie a reakce ruského státu snaží prezentovat nejvyšší političtí představitelé a úřady. Podle ředitelky Federální služby pro dohled nad ochranou práv spotřebitelů (Rospotrebnadzoru) Anny Popovové státní restrikce zabránily nekontrolovanému šírení nákazy a umožnily připravit zdravotnický systém na léčbu postižených, vytvořit zásobu léků a ochranných pomůcek a rozběhnout systém masového testování. Ve zprávě z 28. dubna Rospotrebnadzor zdůraznil, že výrazně klesá procentuální přírůstek nových případů. Významně také roste počet nakažených bez př́znaků, který v celkovém objemu dosahuje téměř $50 \%$. V Murmanské oblasti se neobjevují žádné př́íznaky až u 90 \% nakažených (Кремлин. py 2020). Uvedená čísla dosvědčují, že se úřadům skutečně daří epidemii zvládat. Z hlediska věkové struktury bylo z infikovaných $5 \%$ dětí, $15 \%$ důchodců a $80 \%$ osob v produktivním věku. Těžký průběh má nemoc pouze u $5 \%$ všech pacientů (Ibid.).

\section{Politické a sociální implikace}

Ruské vedení se sice zpočátku zaměřovalo na restriktivní opatření s cílem zabránit šíření epidemie, nejpozději od poloviny března však začalo promýšlet nezbytné kroky sociálního a ekonomického rázu. $V$ obecné rovině mají za cíl alespoň částečnou kompenzaci ztrát na př́ímové straně, podporu malých a středních podniků i rodin s malými dětmi, zjednodušení př́stupu k úvěrům, snížení administrativní zátěže a souvisejících nákladů. Vláda vyhlásila „daňové prázdniny“ pro nejvíce postižená odvětví, dočasně zrušila povinnost odvodů sociálního a zdravotního pojištění, schválila měsíční příspěvky na děti, moratorium na splátky úvěrů, posunula termín podání daňového přiznání, pozastavila finanční kontroly podnikatelů, připravila úvěrové programy se státní garancí či bezúročné půjčky určené na pokrytí mezd pro zaměstnance na půl roku (Хестанов 2020). Potud se 
ekonomická opatření prakticky neliší od těch českých. Na rozdíl od české vlády však ruský prezident navrhl jít cestou navyšování daňové zátěže. Prozatím navrhl zavedení třináctiprocentní daně na úroky z výnosů z vkladů a cenných papírů, jejichž hodnota přesahuje 1 milion rublů, což momentálně odpovídá zhruba 330 tisícům korun. 0 poznání kontroverznější je návrh na patnáctiprocentní zdanění dividend plynoucích do zahraničí. To by totiž vyžadovalo revizi mezinárodních smluv. Prezident už se nechal slyšet, že v př́ípadě nesouhlasu ze strany zahraničních partnerů daň zavede jednostranně, což by bezesporu nezůstalo bez odpovědi (TACC 2020). Ještě dalekosáhlejší důsledky by ale mohlo mít Putinovo tvrzení z konce dubna, podle něhož nemůže být cílem ruského státu ani společnosti pouhá stabilizace a normalizace sociálního a ekonomického života země, tedy obnovení statu quo ante, nýbrž restrukturalizace ruského hospodářství (Кремлин.py 2020). Není však jisté, zda současný prezident bude mít dostatek moci a př́ležitostí k tomuto nesnadnému úkolu, anebo zda jeho řešení, které je předpokladem úspěšného rozvoje země v budoucnu, připadne novým lídrům v podmínkách změněných na základě revize ústavního pořádku.

Prezidentova role za současné krize totiž vyvolává spíše otázky. Vladimir Putin se obzvlášt' v prvních týdnech v řešení krize aktivně neangažoval, v březnu pak krizový management delegoval jednak na premiéra a jím vedenou koordinační radu, jednak na regionální vlády, jednak na pracovní skupinu při Státní radě v čele s moskevským starostou Sergejem Sobjaninem. To začalo záhy vyvolávat jistou rivalitu a soupeření. Zatímco Sobjanin měl primárně zájem na zastavení rychlého šíření epidemie v hlavním městě, které se stalo ohniskem nákazy, a to za pomoci radikálních restrikcí, premiér byl zaměstnán spíše starostmi o ekonomiku, kterou restrikce zásadním způsobem poškozovaly (Stanovaya 2020). Premiérovu roli navíc bezesporu oslabí jeho onemocnění, o němž informoval na přelomu dubna a května. Výkonné pravomoci převzal první vicepremiér Andrej Bělousov, ekonom, bývalý akademik a exministr hospodářského rozvoje, který se později stal Putinovým ekonomickým poradcem a v lednu tohoto roku prvním vicepremiérem ruské vlády. $V$ průběhu dubna se prezident začal pravidelně objevovat v médiích, přesto jeho vystupování vyvolávalo dojem, že se osobně do řešení krize příliš nezapojuje. Podle liberálního politologa Gleba Pavlovského ruskému lídrovi nevyhovuje specifický charakter nového nepř́itele, jímž koronavirová epidemie je, a není ochoten $v$ boji proti němu aktivně vystupovat tak, jak to dělal v př́padě jiných krizí. Jeho popularita podle průzkumů centra Levada za dobu epidemie klesá a pohybuje se kolem $60 \%$. Problémem pro Vladimira Putina může být skutečnost, že veřejnost s ohledem na epidemii není možné oslovovat 
a mobilizovat tradičními tématy, mezi nimiž na předních místech figurovaly zahraničněpolitické otázky. Bude-li proto současný stav trvat příliš dlouho, mohou u veřejnosti začít sílit pochybnosti o legitimitě Putinova vedení, zejména pokud budou přiživovány opozičními silami (Higgins 2020).

Restrikce se také negativně odrazily na celé řadě dlouho očekávaných událostí. Vláda musela odložit na neurčito celonárodní referendum o změnách ústavy, které bylo původně naplánováno na 22. duben, stejně jako oficiální květnové akce u př́ležitosti 75 . výročí konce druhé světové války, kam se původně chystal i český prezident Miloš Zeman. Ve zvláštním duchu proběhlo slavení hlavního křestanského svátku Velikonoc, které letos připadly na 19. dubna. Oficiální stanovisko moskevského patriarchátu respektovalo nařízení státu znemožňující jejich společné a veřejné slavení. Patriarcha Kirill vyzval věřící, aby za současné situace do chrámů nechodili. Skutečnost však byla složitější. V některých regionech byla sice účast věřících na velikonočních bohoslužbách zakázána (například v Moskvě, Sankt-Petěrburgu či na Krymu), jinde ale takový zákaz vyhlášen nebyl. Část duchovenstva se navíc proti zákazům ze strany státu postavila a někteří arcibiskupové se rozhodli věc řešit soudní cestou (Скрипунов 2020). Chrámy byly pro věřící nakonec uzavřeny v polovině ruských regionů. Na některých místech došlo ke konfliktům mezi místními eparchiemi a regionálními vládami. To byl př́ípad Saratova. Jinde několikahodinová noční liturgie probíhala před chrámem bez ohledu na teploty, které se pohybovaly pod bodem mrazu. Ambivalentní postoj pravoslavné církve k restriktivním opatřením, míra benevolence ve vztahu k věříím a jejich aktivní účasti na liturgickém životě církve, jakož i tolerance k zachovávání obvyklé ortopraxe navzdory mimořádné situaci vyvolala kritiku ze strany liberálních kruhů, které se snaží využít situace k útokům na pravoslavnou církev s cílem oslabit její autoritu a vliv v ruské společnosti, které jsou dlouhodobě vysoké (Nykl 2013, 223). Liberální diskurs se ve veřejném prostoru snaží prosadit názor, že právě církev výraznou měrou přispěla k šíření nákazy (Лученко 2020). Účelovost takových tvrzení je při tom zcela zřejmá.

\section{Závěr}

Pro Rusko není primárním rizikem koronavirové epidemie hospodářský propad. Jak naznačila analýza vybraných ekonomických parametrů, ruská ekonomika je schopna útlumu poměrně dlouho čelit. Větším rizikem je epidemiologická či zdravotní stránka a následné sociální konsekvence, jež se nakonec mohou promítnout i v politické rovině. Nepříliš vysoká úroveň 
tamního zdravotnického systému a veřejného zdraví obecně totiž může vést $\mathrm{k}$ relativně vysoké úmrtnosti i při nepř́liš výrazném průběhu epidemie, což by mohlo vyvolat nespokojenost v řadách veřejnosti a těch, kteří dosud Vladimira Putina podporovali.

Toto riziko by mohlo být umocněno $\mathrm{v}$ př́padě, že bude prezident vystupovat nerozhodně, nesystematicky či pasivně. Bude-li současný restriktivní režim s ohledem na potenciálně negativní vývoj epidemie pokračovat delší dobu, mohou se skutečně začít ve veřejném prostoru výrazněji objevovat pochybnosti ohledně legitimity současného politického vedení. Obzvlášt’ budou-li jednotlivé části administrativy a lokální mocenské skupiny využívat situace k posilování vlastního vlivu. Pokud se však prezidentu Putinovi a centrální vládě nevymkne situace z rukou, může z krize vyjít posílena jak ona, tak celá země.

\section{Literatura}

HIGGINS, A. (2020): Putin, Russia's man of action, is passive, even bored, in the coronavirus Era. Web. 1. 5. 2020. <https://www.nytimes.com/2020/04/30/ world/europe/russia-putin-coronavirus.html>.

KIRKHAM, K. (2016): The formation of the Eurasian Economic Union: How successful is the Russian regional hegemony? In: Journal of Eurasian Studies, 7, $111-128$.

NYKL, H. (2013): Náboženství v ruské kultuře. Červený Kostelec: Pavel Mervart.

SERGUNIN, A. (2016): Explaining Russian Foreign Policy Behavior. Theory and Practice. Stuttgart: ibidem Press.

STANOVAYA, T. (2020): Russia's leaders are self-isolating from their people. Web. 25. 4. 2020. <https://carnegie.ru/commentary/81489>.

TABAKH, A. (2020): Russia battles new economic crisis on three fronts. Web. 30. 4. 2020. <https://carnegie.ru/commentary/81321>.

THE ECONOMIST (2020): Russia's economy is isolated from the global rout. Web. 30. 4. 2020. <https://www.economist.com/europe/2020/03/26/ russias-economy-is-isolated-from-the-global-rout>.

TRENIN, D. (2020): Confronting the challenges of coronavirus, Russia sees its worldview vindicated. Web. 1. 5. 2020. <https://carnegie.ru/commentary/81335>.

КРЕМЛИН.РУ (2020): Совещание с руководителями субъектов Федерации по вопросам противодействия распространению коронавирусной инфекции. Web. 1. 5. 2020. <http://kremlin.ru/events/president/news/ 63288>.

ЛЕВАДА-ЦЕНТР (2020): Пандемия: Меры властей и „нерабочие недели“. Web. 1. 5. 2020. <https://www.levada.ru/2020/04/30/pandemiya-mery-inerabochie-nedeli/>.

ЛУЧЕНКО, К. (2020): Широко закрытые двери. Что случилось с русской церковью во время пандемии. Web. 27. 4. 2020. <https://carnegie.ru/ commentary/81681>. 
СКРИПУНОВ, А. (2020): В каких регионах пустят в храм на Пасху, а в каких нет. Web. 22. 4. 2020. <https://ria.ru/20200416/1570053686.html>.

СТОПКОРОНАВИРУС.РФ (2020): Оперативные данные. Web. 2. 5. 2020. <https://стопкоронавирус.рф/information/>.

TACC (2020): Путин предложил установить налог за вывод дивидендов в офшоры в размере 15 \%. Web. 25. 4. 2020. <https://tass.ru/ekonomika/ 8075393>.

ФЕДЕРАЛЬНАЯ СЛУЖБА ПО НАДЗОРУ В СФЕРЕ ЗАЩИТЫ ПРАВ ПОТРЕБИТЕЛЕЙ И БЛАГОПОЛУЧИЯ ЧЕЛОВЕКА (2020): НовосТИ о коронавирусе. Web. 2. 5. 2020. <https://rospotrebnadzor.ru/about/info/ news $/>$.

ХЕСТАНОВ, С. (2020): Инерционный пакет Путина. Приведет ли шок от коронавируса к переменам в России. Web. 20. 4. 2020. <https://carnegie. $\mathrm{ru} /$ commentary/81373>.

ШРАЙБМАН, А. (2020): Куда коронавирус ведет отношения Минска и Москвы. Web. 27. 4. 2020. <https://carnegie.ru/commentary/81595>.

\section{PhDr. Ladislav Zemánek}

Ústav světových dějin, Filozofická fakulta Univerzity Karlovy

Nám. Jana Palacha 2

11638 Praha 1

zemanek.ml@gmail.com 